\title{
Патофізіологічні особливості системної гемодинаміки та кисневого забезпечення тканин у хворих на синдром обструктивного апное- гіпопное сну вдень
}

\begin{abstract}
Мета роботи: дослідити особливості функціонування системної гемодинаміки та кисневого забезпечення тканин у хворих на синдром обструктивного апное-гіпопное сну (СОАГС) у період їхньої активності (удень).

Матеріали і методи. Дослідження проведено у 66 хворих на СОАГС. Групу контролю склали особи такого ж віку та маси тіла, у котрих СОАГС при полісомнографічному дослідженні не підтвердився.

Результати досліджень та їх обговорення. Проведено дослідження системної гемодинаміки та кисневого балансу: особливостей порушень надходження кисню (ступінь легеневої гіпоксії), зв’язування кисню гемоглобіном (ступінь гемічної гіпоксії), ефективності забезпечення надходження кисню до тканин (інтегрального показника кисневої недостатності) у хворих на СОАГС. Встановлено, що вдень синхронно тяжкості патології зростає активність серцево-судинної системи: серцевого викиду, частоти серцевих скорочень та загального периферичного судинного опору.

При цьому найбільш інформативним виявився індекс Робінсона, який порівняно з показниками в осіб групи котролю -

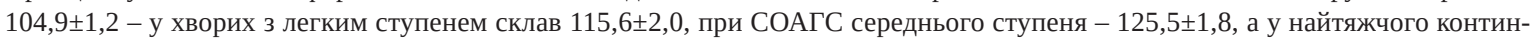
генту - 137,1士2,1-, що є предиктором розвитку артеріальної гіпертензії та органних порушень.
\end{abstract}

Ключові слова: синдром обструктивного апное-гіпопное сну; системна гемодинаміка; гіпоксія; кисневе забезпечення тканин.

Постановка проблеми і аналіз останніх досліджень та публікацій. Синдром обструктивного апное-гіпопное (СОАГС) під час сну - патологічний стан зупинки вентиляції легень понад 10 с; при цьому впродовж 7-годинного сну апное-гіпопное реєструється не менше 30 разів [1]. Кожен період апное завершується мікропробудженням та гіпервентиляцією, що зумовлено активацією симпатичної нервової системи та гіперкатехоламінемією [2].

Цей синдром значно поширений. Наприклад, у США на таку патологію страждає понад 12 мільйонів людей.

У хворих на СОАГС виникає ряд порушень зі сторони серцево-судинної системи; пріоритетним при цьому виступає артеріальна гіпертензія, порушення серцевого ритму та органні пошкодження [3].

Мета роботи: дослідити особливості функціонування системної гемодинаміки та кисневого забезпечення тканин у хворих на СОАГС у період їхньої активності (удень).

Матеріали і методи Дослідження проведено у 66 хворих на СОАГС. Групу контролю склали особи такого ж віку та маси тіла, у яких СОАГС при полісомнографічному дослідженні не підтвердився.

У пацієнтів вимірювали частоту серцевих скорочень, артеріальний тиск, серцевий викид (ехосонографічно); обчислювали їхні індекси та за- гальний периферичний судинний опір, коефіцієнт економізації кровообігу (KEK) та індекс Робінсона (IP). У хворих визначали вміст гемоглобіну, еритроцитів, гематокриту, сатурацію артеріальної крові $\left(\mathrm{SpO}_{2} \mathrm{a}\right)$, обчислювали вміст кисню в артеріальній крові, еритроцитний викид та об'єм кисню, який транспортується до тканин $\left(\mathrm{УOO}_{2} \mathrm{XOO}_{2}\right)$ [4].

Для дослідження ефективності кисневого забезпечення тканин ми застосували такий методологічний підхід.

Досліджували ступінь гемічної гіпоксії:

а) за показником гемоглобіну $\left.\left(\mathrm{Hb}, \Gamma^{\cdot}\right)^{-1}\right)$ розраховували кисневу ємність крові (КЄК), застосовуючи константу Г. Гюфнера:

$$
\mathrm{K} € \mathrm{~K}=\mathrm{Hb} \cdot 1,36\left(\text { мл} \cdot \pi^{-1}\right)
$$

б) розраховували кисневу ємність крові оптимальну (КЄКо) - максимальний об’єм кисню, який здатний вмістити 1 літр крові при стандартних умовах “ідеальних легень” та показнику активної фракції гемоглобіну в нормі $\left(120 \Gamma \cdot \pi^{-1}-\right.$ нижня границя норми) [9]; (2)

в) ступінь зниження кисневої ємності крові пацієнта, порівняно із оптимальною, становитиме ступінь гемічної гіпоксії [4]:

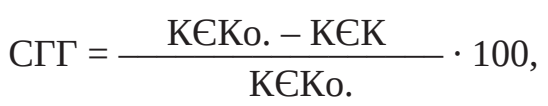

де СГГ - ступінь гемічної гіпоксії, \% 
г) обчислювали вміст кисню в артеріальній крові $\left(\mathrm{CaO}_{2}\right)$ :

$$
\mathrm{CaO}_{2}=\mathrm{SpO}_{2} \mathrm{a} \cdot \mathrm{K} \epsilon \text { Kф. }\left(\text { мл } \cdot \Omega^{-1}\right)
$$

д) зниження вмісту кисню в артеріальній крові, зумовлене патологією зовнішнього дихання ступінь легеневої гіпоксії - становитиме:

$$
\text { СЛГ }=\frac{0,96 \mathrm{KEK}-\mathrm{CaO}_{2}}{0,96 \mathrm{KEK}} \cdot 100,
$$

де СЛГ - ступінь легеневої гіпоксії, \%

е) за показником $\mathrm{CaO}_{2}$ та об'ємом серцевого викиду обчислювали об'єм кисню, який проштовхує серце при кожній систолі $\left(\mathrm{УOO}_{2}\right)$, впродовж хвилини $\left(\mathrm{XOO}_{2}\right)$ та з розрахунку на площу поверхні тіла у $1 \mathrm{~m}^{2}$, визначали індекс транспортування кисню реальний $\left(\mathrm{ITO}_{2} \mathrm{p}\right)$;

$\epsilon)$ обчислювали індекс транспорування кисню оптимальний $\left(\mathrm{ITO}_{2} \mathrm{O}\right)$ за показниками оптимальної роботи серця особи даної вікової групи - СІо та оптимальної кисневої ємності крові - КЄКо.

$$
\mathrm{ITO}_{2} \mathrm{O} .=\text { CIo·KEKo, }
$$

ж) при зіставленні результатів вимірювань $\mathrm{ITO}_{2} \mathrm{O}$ та $\mathrm{ITO}_{2} \mathrm{p}$ можна визначити на скільки відсотків об'єм транспортованого до тканин кисню знижений (або підвищений) порівняно з його спроможністю (так званий інтегральний показник кисневої недостатності, ІПКН) [4];
3) ІПКН включає усі причини, які призводять до зниження оксигенації тканин: гемічні, легеневі та циркуляторні:

$$
\mathrm{I \Pi KH}=\text { СГГ }+\mathrm{CЛГ}+\mathrm{CЦГ,}
$$

де СГГ - ступінь гемічної гіпоксії, \%

СЛГ - ступінь легеневої гіпоксії, \%

СЦГ - ступінь циркуляторної гіпоксії, \%.

Результати досліджень та їх обговорення. Результати досліджень гемодинаміки у хворих на СОАГС удень відображено в таблиці 1.

Порівняно з показниками групи контролю у хворих на СОАГС виявлено артеріальну гіпертензію (АТсист., АТдіаст., САТ) і зростання частоти серцевих скорочень. Патофізіологічною причиною такого стану виступало достовірне підвищення серцевого викиду (УОС, УІ та ХОС, СІ), яке корелювало із тяжкістю патології.

Коефіцієнт економізації кровообігу (КЕК) в усіх хворих (як дослідної, так і контрольної групи) удень виявився вищим понад норму.

Індекс Робінсона (IP), який характеризує ефективність функціонування серцево-судинної системи, виявився найбільш інформативним, прогресивно наростаючи відповідно до тяжкості патології.

Загальний периферичний судинний опір (ЗПОС) у пацієнтів відповідав показникам верх-

\begin{tabular}{|c|c|c|c|c|}
\hline \multirow{2}{*}{ Показник } & \multirow{2}{*}{$\begin{array}{c}\text { Показники } \\
\text { контрольноїгрупи }\end{array}$} & \multicolumn{3}{|c|}{ Хворі на СОАС різного ступеня тяжкості: } \\
\hline & & легкого & середнього ступеня & тяжкого \\
\hline ЧСС, уд хвв. ${ }^{-1}$ & $76,0 \pm 2,0$ & $79,9 \pm 1,6$ & $84,1 \pm 1,8$ & $86,2 \pm 1,2 *$ \\
\hline АТ сист., кПа & $18,4 \pm 0,3$ & $19,3 \pm 0,3$ & $19,9 \pm 0,3$ & $21,2 \pm 0,3^{*}$ \\
\hline АТ діаст, кПа & $11,3 \pm 0,2$ & $13,0 \pm 0,3$ & $13,6 \pm 0,2$ & $15,5 \pm 0,2 *$ \\
\hline САТ, кПа & $13,7 \pm 0,2$ & $15,1 \pm 0,3$ & $15,7 \pm 0,1$ & $17,4 \pm 0,2 *$ \\
\hline УОС, мл & $73,1 \pm 2,7$ & $79,3 \pm 3,6$ & $79,4 \pm 3,1^{*}$ & $86,2 \pm 3,1^{*}$ \\
\hline УІ, мл $\cdot \mathrm{M}^{-2}$ & $34,8 \pm 1,4$ & $37,8 \pm 2,2$ & $37,8 \pm 2,7$ & $41,0 \pm 1,9 * *$ \\
\hline ХОСо., л $\cdot \mathrm{XB}^{-1}$ & $5,56 \pm 0,09$ & $5,53 \pm 0,08$ & $5,36 \pm 0,11 *$ & $5,41 \pm 0,10 *$ \\
\hline ХОС, $л \cdot \mathrm{XB}^{-1}$ & $5,55 \pm 0,21$ & $6,34 \pm 0,20$ & $6,68 \pm 0,19$ & $7,43 \pm 0,22 *$ \\
\hline CI, $л \cdot \mathrm{XB}^{-1} \mathrm{M}^{-2}$ & $2,64 \pm 0,1$ & $3,02 \pm 0,2$ & $3,18 \pm 0,3$ & $3,54 \pm 0,2$ \\
\hline IP & $104,9 \pm 1,2$ & $115,6 \pm 2,0$ & $125,5 \pm 1,8 * *$ & $137,1 \pm 2,1^{* *}$ \\
\hline ЗПОС, дин $\cdot \mathrm{cek}^{-1} \cdot \mathrm{c}^{-1} \cdot \mathrm{cm}^{-5}$ & $1481,0 \pm 35,6$ & $1429,0 \pm 26,4$ & $1410,2 \pm 31,2$ & $1405,1 \pm 35,1$ \\
\hline
\end{tabular}
ньої границі норми або був незначно (недостовірно) підвищеним.

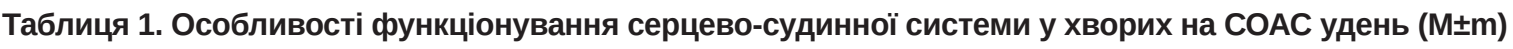

Примітка: *-p<0,05; ** - p < 0,01 порівняно з показниками в осіб групи контролю. 
Таким чином, у хворих на СОАГС внаслідок частих нічних епізодів зупинки дихання у денний час формується гіпердинамічний режим кровообігу, зумовлений підвищенням роботи серця, а клінічним його проявом виступає артеріальна гіпертензія.

Установлено, що в міру наростання тяжкості патології, порівняно з пацієнтами групи контролю, у хворих на СОАГС зростали гемоконцентраційні показники (кількість еритроцитів, гемоглобін та гематокрит). Такий феномен свідчить про те, що при періодично виникаючій гіпоксичній гіпоксії та гіпоксемії під час сну, яка при СОАГС набуває хронічної форми, в організмі відбуваються процеси активізації еритропоезу.

При цьому феномен вторинного еритроцитозу, очевидно, зумовлений компенсаторним механізмом: підвищення концентрації переносників кисню (гемоглобіну) сприяє підвищенню спроможності артеріальної крові вмістити додатковий об'єм кисню при гіпоксичній гіпоксії, яка виникає внаслідок обструкції верхніх дихальних шляхів у хворих під час сну та може сягати критичних значень.

Киснева ємність крові (КЄК) в усіх хворих, 3 різним ступенем тяжкості виявилась підвищеною: від $(170,2 \pm 2,8)$ до $(188,8 \pm 1,8)$ мл ${ }^{-1}$. При цьому в усіх пацієнтів гемічної гіпоксії не виявлено, іï показник становив цифру зі знаком “мінус", що свідчить про спроможність гемоглобіну “зв’язати” більшу понад норму кількість молекул кисню.

У хворих з легкими проявами патології ступінь гемічної гіпоксії виявився $(-2,7 \pm 0,1) \%$, у пацієнтів з патологією середнього ступеня $(-8,9 \pm 0,3)$ та у хворих тяжкого ступеня $(-10,9 \pm 0,6) \%$.
Така позитивна з позицій збереження кисневого гомеостазу організму набута під впливом гіпоксії компенсаторна вторинна поліцитемія неминуче супроводжується підвищенням в'язкості крові. Підтвердженням цього було зростання в пацієнтів гематокриту від $(0,42 \pm 0,1)$ до $(0,45 \pm 0,2) \pi \cdot \pi^{-1}$, що корелювало із тяжкістю патології. Разом з тим, така особливість зміни густини крові є важливим фактором ризику формування тромбів у судинному руслі та виникнення тромбогенних ускладнень, до яких схильні хворі на СОАГС [6].

Необхідно зазначити, що в міру прогресування тяжкості патології в пацієнтів більш інтенсивно зростала кількість еритроцитів (на 12,2 \%) порівняно з рівнем гемоглобіну (на 10,2 \%).

Сатурація артеріальної крові у хворих на СОАГС у денний час не була порушена, її цифрові значення, отримані при пульсоксиметрії, в основному відповідали встановленим як в осіб групи контролю, так і показникам норми, притаманним людям даної вікової групи. Тому ступінь легеневої гіпоксії в пацієнтів у денний час становив $1-2 \%$.

Вміст кисню в артеріальнй крові $\left(\mathrm{CaO}_{2}\right)$ усіх пацієнтів у денний час синхронно тяжкості патології та зростання концентрації гемоглобіну також підвищувався від $(165,8 \pm 2,4)$ до $(177,2 \pm 2,3)$ мл ${ }^{-1}{ }^{-}$.

Показники кисневого забезпечення тканинного дихання подано в таблиці 3.

Якщо індекс транспортування кисню оптимальний $\left(\mathrm{ITO}_{2}\right.$ о.) визначає, який об’єм кисню потрібно проштовхувати серцю у велике коло кровообігу для забезпечення метаболічних реакцій

Таблиця 2. Особливості кисневого балансу на етапі “легені-кров” у хворих на СОАГС у період

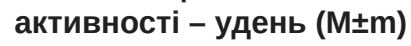

\begin{tabular}{|c|c|c|c|c|}
\hline \multirow[b]{2}{*}{ Показник } & \multirow{2}{*}{$\begin{array}{c}\text { У осіб } \\
\text { контрольної } \\
\text { групи, } \mathrm{n}=20\end{array}$} & \multicolumn{3}{|c|}{ Групи хворих за ступенем тяжкості } \\
\hline & & $\begin{array}{c}\text { легкий, } \\
\text { n = } 28\end{array}$ & $\begin{array}{c}\text { середнього } \\
\text { ступеня, } \mathrm{n}=23\end{array}$ & $\begin{array}{c}\text { тяжкий } \\
\text { n = } 15\end{array}$ \\
\hline Еритроцити, $10^{12} \pi^{-1}$ & $4,4 \pm 0,2$ & $4,3 \pm 0,3$ & $4,7 \pm 0,2$ & $5,0 \pm 0,2 * *$ \\
\hline $\mathrm{Hb}, \Gamma \cdot \pi^{-1}$ & $125,4 \pm 2,2$ & $126,3 \pm 1,8$ & $136,4 \pm 2,5$ & $138,2 \pm 3,1^{*}$ \\
\hline Нt, л• $\pi^{-1}$ & $0,42 \pm 0,02$ & $0,42 \pm 0,1$ & $0,43 \pm 0,2$ & $0,45 \pm 0,1^{*}$ \\
\hline $\mathrm{SpO}_{2} \mathrm{a}, \%$ & $95,5 \pm 0,2$ & $94,8 \pm 0,4$ & $93,9 \pm 0,3$ & $93,8 \pm 0,5$ \\
\hline КЕК, мл• $\pi^{-1}$ & $170,2 \pm 2,8$ & $174,8 \pm 1,2$ & $185,5 \pm 2,3^{* *}$ & $188,8 \pm 1,8 * *$ \\
\hline $\mathrm{CaO}_{2}, \mathrm{мл} \cdot \pi^{-1}$ & $165,0 \pm 4,0$ & $165,8 \pm 2,4$ & $174,2 \pm 3,1^{*}$ & $177,2 \pm 2,3^{* *}$ \\
\hline СГГ, \% & $0,0 \pm 0,3$ & $-2,7 \pm 0,1^{* *}$ & $-8,9 \pm 0,3 * *$ & $-10,9 \pm 0,6^{* *}$ \\
\hline СЛГ, \% & $0,0 \pm 0,3$ & $+1,0 \pm 0,3^{*}$ & $+2,0 \pm 0,3^{* *}$ & $+2,0 \pm 0,4^{* *}$ \\
\hline
\end{tabular}

Примітка: * - p<0,05, * - p<0,01 порівняно з показниками в осіб контрольної групи. 


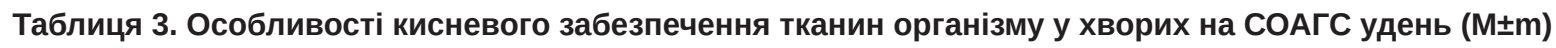

\begin{tabular}{|c|c|c|c|c|}
\hline \multirow{2}{*}{ Показник } & \multirow{2}{*}{$\begin{array}{c}\text { Показники контрольної } \\
\text { групи }\end{array}$} & \multicolumn{3}{|c|}{ Хворі на СОАГС різного ступеня тяжкості } \\
\hline & & легкого & середньої тяжкості & тяжкого \\
\hline $\mathrm{УOO}_{2}$, мл & $12,0 \pm 0,3$ & $13,1 \pm 0,5^{*}$ & $13,8 \pm 0,4^{* *}$ & $15,3 \pm 0,6^{* *}$ \\
\hline 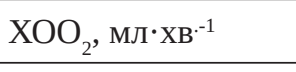 & $912,4 \pm 39,0$ & $1050,2 \pm 47,0^{* *}$ & $1162,0 \pm 41,4^{* *}$ & $1318,9 \pm 48,6^{* *}$ \\
\hline $\mathrm{EB}, \pi \cdot \mathrm{M}^{-2}$ & $1,26 \pm 0,03$ & $1,26 \pm 0,03$ & $1,39 \pm 0,03 * *$ & $1,62 \pm 0,06 * *$ \\
\hline $\mathrm{ITO}_{2} \mathrm{O} . \mathrm{M} \cdot \mathrm{xB}^{-1} \mathrm{M}^{-2}$ & $493.4 \pm 16,4$ & $506,7 \pm 13,9$ & $560,2 \pm 16,7^{* *}$ & $547,4 \pm 21,5^{* *}$ \\
\hline $\mathrm{ITO}_{2} \mathrm{p} ., \mathrm{M} л \cdot \mathrm{xB}^{-1} \cdot \mathrm{M}^{-2}$ & $498,3 \pm 17,0$ & $500,7 \pm 19,8$ & $554,0 \pm 22,1^{*}$ & $627,2 \pm 24,7^{* *}$ \\
\hline ІПКН, \% & $+0,5 \pm 0,3$ & $+1,2 \pm 0,1^{*}$ & $+1,1 \pm 0,1^{*}$ & $-14,5 \pm 0,4^{* *}$ \\
\hline
\end{tabular}

Примітка: * - p<0,05; ** - p<0,01 порівняно з показниками в осіб контрольної групи.

організму (з розрахунку на площу тіла $1 \mathrm{~m}^{2}$ за хвилину), то індекс транспортування кисню реальний (ITO 2 .) вказує, який саме об’єм кисню у дану конкретну хвилину перекачує серце.

При зіставленні результатів вимірювань індексу транспортування кисню оптимального та індексу транспортування кисню реального можна визначити, на скільки відсотків об'єм транспортованого до тканин кисню понижений (або підвищений) порівняно з його спроможністю.

На величину ІПКН впливає, з одного боку, інтенсивність тканинного дихання (енергетичного обміну), з іншого - спроможність організму його забезпечити: гемічним компонентом (його характеризує ступінь гемічної гіпоксії, СГГ), легенями (вимірюється ступенем легеневої гіпоксії, СЛГ), серцево-судинною системою (при цьому визначається ступінь циркуляторної гіпоксії, СЦГ).

Цифровий вираз ІПКН складається із суми ступенів гіпоксій, які виникають на наступних етапах кисневого каскаду: надходження кисню до крові (легеневої гіпоксії), сполучення його з гемоглобіном (гемічної гіпоксії), транспортування до тканин (циркуляторної гіпоксії) та вимірюється у відсотках (7).

Показник із знаком “+” вказує на зниження питомої частки даного компонента у забезпеченні кисневого балансу організму (найчастіше - внаслідок патології), а знак “-” - на його підвищення.

Після виділення окремих елементів кисневого балансу, які забезпечують підтримування тканинного метаболізму, та визначення ступеня їхніх проявів можна отримати динамічну картину процесів, які відбуваються в організмі у будь-який конкретний момент при будь-яких його патологічних станах. Такий патофізіологічний “зріз” особливостей забезпечення кисневого гомеостазу організму можна трактувати як “патерн кисневого балансу організму”.
Встановлено, що у хворих на СОАГС удень інтегральний показник кисневої недостатності виявився суттєво вищим від норми: на (мінус $14,5 \pm 0,4)$ \% лише у пацієнтів з найтяжчою патологією, що вказує на найбільш виражену них компенсаторну реакцію організму - вторинну поліцитемію - на нічні порушення оксигенації. У хворих легкого та середнього ступеня тяжкості ІПКН суттєво не відрізнявся від показника контрольної групи.

Еритроцитний викид (ЕВ) в усіх пацієнтів прогресивно зростав сягаючи у найтяжчих хворих значень $(1,62 \pm 0,06) \pi \cdot \mathrm{m}^{-2}$, що достовірно $(\mathrm{p}<0,01)$ вище від показників, отриманих в осіб контрольної групи.

Було проведено диференціацію гіпоксій, які склали загальний результат ІПКН у хворих на СОАГС у денний час (табл. 4).

У хворих контрольної групи ІПКН суттєво не відрізнявся від норми, відповідно, ступені усіх гіпоксій були близькими до “0”.

У хворих із легким ступенем доставка кисню до тканин удень на $(1,2 \pm 0,2)$ \% відрізняється від фізіологічної потреби, причому система гемодинаміки працює у незначному ощадному режимі (СЦГ становить $+2,9 \pm 0,3$ \%) за рахунок того, що включається компенсаторний механізм гемічного генезу

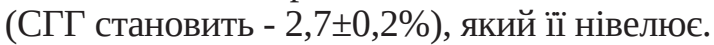

У хворих із середнім ступенем тяжкості спостерігається уже більш значна компенсаторна реакція гемічного компонента, завдяки чому для стабілізації нормальних значень ІПКН серцевосудинній системі не потрібно працювати в надмірному режимі для забезпечення кисневого балансу, тому СЦГ становить $(+8,0 \pm 0,2) \%$.

У хворих на тяжку патологію виявлено суттє-

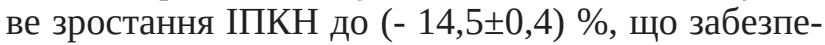
чується компенсаторною реакцією як гемічного

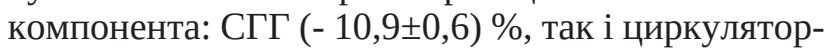
ного: СЦГ $(-5,6 \pm 0,4) \%$. 
Таблиця 4. Ступені гіпоксій (гемічної, легеневої та циркуляторної) у хворих на СОАГС удень (М士m)

\begin{tabular}{||l|c|c|c|c||}
\hline \multirow{2}{*}{ Показник } & \multirow{2}{*}{$\begin{array}{c}\text { Показники } \\
\text { контрольноїгрупи }\end{array}$} & \multicolumn{2}{|c|}{ Хворі на СОАГС різного ступеня тяжкості } \\
\cline { 3 - 5 } & & легкого & середньої тяжкості & тяжкого \\
\hline ІПКН, \% & $+0,5 \pm 0,3$ & $+1,2 \pm 0,2$ & $+1,1 \pm 0,1$ & $-14,5 \pm 0,4 * *$ \\
\hline СГГ, \% & $0,0 \pm 0,3$ & $-2,7 \pm 0,2 * *$ & $-8,9 \pm 0,3 * *$ & $-10,9 \pm 0,6^{* *}$ \\
\hline СЛГ \% & $+0,4 \pm 0,1$ & $+1,0 \pm 0,1$ & $+2,0 \pm 0,1^{*}$ & $+2,0 \pm 0,1^{*}$ \\
\hline СЦГ, \% & $+0,1 \pm 0,3$ & $+2,9 \pm 0,3 * *$ & $+8,0 \pm 0,2^{* *}$ & $-5,6 \pm 0,4^{* *}$ \\
\hline \hline
\end{tabular}

Примітка: * - p<0,05; ** - p<0,01 порівняно з показниками в осіб контрольної групи.

В останньому варіанті клінічними проявами такої циркуляторної гіпоксії із знаком “-” у пацієнтів на СОАГС виступає зростання серцевого викиду та артеріальна гіпертензія.

Висновки. 1. Активація симпатичної нервової системи уночі, під час нападів апное-гіпопное призводить до гіперфункції серцево-судинної системи синхронно тяжкості патології, який проявляється зростанням серцевого викиду, частоти серцевих скорочень та загального периферичного судинного опору.

\section{СПИСОК ЛІТЕРАТУРИ}

1. Diagnosis and treatment of obstructive sleep apnea in adults [Text] / Institute for Clinical System Improvement / Health Care Guideline // Sixth Edition - 2008. - P. 8-9.

2. Bourjeily G. Sleep disordered breathing in pregnancy / G. Bourjeily, G. Ankner, V. Mohsenin // Clin. Chest Med. 2011. - Vol. 32. - P. 175-189.

3. Resistent hypertension: diagnosis, evaluation, and treatment. A scientific statement from the American Heart Association Professional Education of the Council for High Blood Pressure Research / D. A. Calhoun, D. Jones, S. Textor [et al.] // Hypertension. - 2008. - Vol. 51. - P. 1897-1904.

\section{REFERENCES}

1. (2008). Diagnosis and treatment of obstructive sleep apnea in adults. Institute for Clinical System Improvement. Health Care Guideline.

2. Bourjeily, G., Ankner, G., \& Mohsenin, V. (2011). Sleep disordered breathing in pregnancy. Clin. Chest Med., 32, 175-189.

3. Calhoun, D.A., Jones, D., \& Textor, S. (2008). Resistent hypertension: diagnosis, evaluation, and treatment. A scientific statement from the American Heart Association Professional Education of the Council for High Blood Pressure Research. Hypertension, 51, 1897-1904.

4. Hnativ, V.V. (2003). Sposib doslidzennia kysnevoho balansu [Method of studying oxygen balance]. Bil, znebolennia i in-
2. Удень найбільш інформативним виявився індекс Робінсона, який порівняно з показниками у осіб групи котролю - $(104,9 \pm 1,2)$ у хворих легкого ступеня склав $(115,6 \pm 2,0)$, при СОАГС середнього ступеня - $(125,5 \pm 1,8)$, а у найтяжчого контингенту - $(137,1 \pm 2,1)$.

3. Гіперкатехоламінемія, зумовлена нічними нападами апное-гіпопное, є предиктором розвитку артеріальної гіпертензії та органних порушень, а компенсаторна активація еритропоезу - підвищенню в'язкості крові, що є важливим фактором тромбогенних ускладнень.

4. Гнатів В. В. Спосіб дослідження кисневого балансу / В. В. Гнатів // Біль, знеболювання і інтенсивна терапія. 2003. - № 1. - С. 22-28.

5. Об интегральной оценке кислородного режима в послеоперационном периоде / Ю. Н. Шанин, А. Л. Костюченко, М. И. Тищенко, И. П. Николаева // Вестн. АМН СССР. 1976. - № 11. - C. 42-47.

6. Любшина О. В. Нарушения сна у больных с метаболическим синдромом и хроническими цереброваскулярными заболеваниями: автореферат дис. ... д. мед. н. / О. В. Любшина. Москва, 2010.

tensyvna terapiia - Pain, Analgesia and Intensive Care, 1, 22-28. 5. Shanin, Yu.N., Kostiuchenko, A.L., \& Nikolaeva, I.P. (1976). Ob integralnoy otsenke kislorodnogo rezhima v posleoperatsionom periode [On the integral assessment of the oxygen regime in the postoperative period]. Vestn. AMN SSSR - Bulletin of USSR Academy of Medical Sciences, 11, $42-47$ [in Russian].

6. Liubshyna, O.V. (2010). Narusheniya sna u bolnykh s metabolicheskim sindromom i khronicheskim tserebrovaskulyarnymi zabolevaniyami [Sleep disorders in patients with metabolic syndrome and chronic cerebrovascular diseases]. Doctor's Extended abstract. Moscow [in Russian]. 
R. E. SOLTANI

I. Horbachevsky Ternopil National Medical University

\title{
PATHOPHYSIOLOGICAL FEATURES OF SYSTEMIC HEMODYNAMICS AND OXYGEN SUPPLY OF TISSUES IN PATIENTS WITH OBSTRUCTIVE SLEEP APNEA-HYPOPNEA SYNDROME DURING THE DAY
}

\begin{abstract}
The aim of the work: to study the peculiarities of the functioning of systemic hemodynamics and oxygen supply of tissues in patients with obstructive sleep apnea-hypopnea syndrome (OSAHS) during their activity (day).

Materials and Methods. The study was conducted in 66 patients with OSAHS. The control group consisted of individuals of the same age and body weight, in whom OSAHS was not confirmed by polysomnographic examination.

Results and Discussion. A study of systemic hemodynamics and oxygen balance: features of oxygen supply disorders (degree of pulmonary hypoxia), oxygen binding by hemoglobin (degree of hemic hypoxia), the effectiveness of oxygen supply to tissues (integrated indicator of oxygen deficiency) in patients with OSAHS. It was established that during the day, synchronously with the severity of the pathology, the activity of the cardiovascular system increases: cardiac output, heart rate and total peripheral vascular resistance.

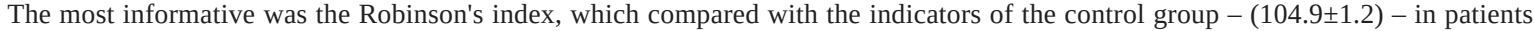
with mild was (115.6 \pm 2.0$)$, with OSAHS moderate - (125.5 \pm 1.8$)$, and in the most severe contingent - (137.1 \pm 2.1$)$ - which is a predictor of the development of arterial hypertension and organ disorders.
\end{abstract}

Key words: obstructive sleep apnea-hypopnea syndrome; systemic hemodynamics; hypoxia; oxygen supply to tissues.

Р. Е. СОЛТАНИ

Тернопольский национальный медицинский университет имени И. Я. Горбачевского МОЗ Украины

\section{ПАТОФИЗИОЛОГИЧЕСКИЕ ОСОБЕННОСТИ СИСТЕМНОЙ ГЕМОДИНАМИКИ И КИС.ЛОРОДНОГО ОБЕСПЕЧЕНИЯ ТКАНЕЙ У БОЛЬНЫХ С СИНДРОМОМ ОБСТРУКТИВНОГО АПНОЭ-ГИПОПНОЭ СНА В ДНЕВНОЕ ВРЕМЯ}

\begin{abstract}
Цель работы: исследовать особенности функционирования системной гемодинамики и кислородного обеспечения тканей у больных с синдромом обструктивного апноэ-гипопноэ сна (СОАГС) в период их активности (днем).

Материалы и методы. Исследование проведено в 66 больных на СОАГС. Группу контроля составили лица такого же возраста и массы тела, в которых СОАГС при полисомнографическому исследовании не подтвердился.

Результаты исследований и их обсуждение. Проведено исследование системнойгемодинамики икислородного баланса: особенностейнарушенийпоступлениякислорода (степеньлегочнойгипоксии), связываниякислородагемоглобином(степеньгемической гипоксии), эффективности обеспечения поступления кислорода к тканям (интегрального показателя кислородной недостаточности) в больных на СОАГС. Установлено, что в дневное время синхронно тяжести патологии растет активность сердечно-сосудистой системы : сердечных выбросов, частоты сердечных сокращений и общего периферического сосудистого сопротивления. При этом наиболее информативным оказался индекс Робинсона, который сравнительно с показателями у лиц группы контроля

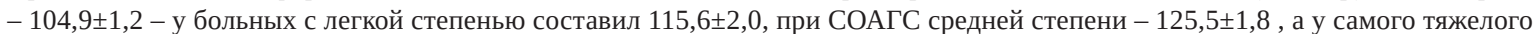
контингента $-137,1 \pm 2,1$, что является предиктором развития артериальной гипертензии и органных нарушений.
\end{abstract}

Ключевые слова: синдром обструктивного апноэ-гипопноэ сна; системная гемодинамика; гипоксия; кислородное обеспечение. 